\title{
URGENSI PENDIDIKAN MULTIKULTURAL SEBAGAI UPAYA MENINGKATKAN APRESIASI SISWA TERHADAP KEARIFAN BUDAYA LOKAL
}

\author{
Heri Cahyono \& Iswati \\ Fakultas Agama Islam Universitas Muhammadiyah Metro \\ Jl. Ki Hajar Dewantara No.166 Kota Metro Lampung 34111 \\ e-mail: hericahyono808@gmail.com E iswatiummetro@yahoo.com
}

\begin{abstract}
Indonesia is a pluralistic country. Plurality, apart to become a wealth and pride, of course also be a crucial challenge. Multicultural education is an activity in developing human potential that is able to appreciate the wide range of differences and an effort to increase students' appreciation of the wisdom of the local culture. This paper is a literature review encouraging the multicultural education as an educational concept that is very urgent to be implemented in the education unit, given once occurred various problems of conflicts caused by cultural differences. This paper examines how the concept of multicultural education, multicultural education curriculum development in schools, the development of multicultural education in the school curriculum, and the role of multicultural education in improving the students' appreciation of the local cultural wisdom.
\end{abstract}

Keywords: multicultural Education, the students' appreciation, local wisdom

\begin{abstract}
Abstrak
Indonesia merupakan negara yang majemuk. Kemajemukan selain mampu menjadi sebuah kekayaan dan kebanggaan tentu juga menjadi sebuab tantangan yang krusial. Pendidikan multikultural merupakan suatu kegiatan dalam mengembangkan potensi manusia yang mampu menghargai berbagai macam perbedaan dan sebagai usaha dalam meningkatkan apresiasi siswa terhadap kearifan budaya lokal yang ada. Tulisan ini merupakan sebuah kajian literatur yang memandang pendidikan multikultural merupakan sebuah konsep pendidikan yang sangat urgent untuk diimplementasikan dalam satuan pendidikan, mengingat kerap sekali terjadi berbagai permasalahan konflik yang dilatar belakangi oleh perbedaan budaya. Tulisan ini mengkaji bagaimana konsep pendidikan multikultural, pengembangan kurikulum pendidikan multikultural di sekolah, pengembangan kurikulum pendidikan multikultural di sekolah, dan peran pendidikan multikultural dalam meningkatkan apresiasi siswa terhadap kearifan budaya lokal.
\end{abstract}

Kata kunci: pendidikan multikultural, apresiasi siswa, budaya lokal 


\section{Pendahuluan}

Indonesia merupakan salah satu negara terbesar di dunia, sebagai negara yang memiliki jumlah penduduk sekitar 249,9 juta jiwa ini menunjukan bahwa bangsa indonesia sangat beragam dilihat dari kondisi sosio-kultural yang beraneka ragam. Nasikun menjelaskan bahwa kemajemukan masyarakat Indonesia paling tidak dapat dilihat dari dua cirinya yang unik, pertama secara horizontal, ia ditandai oleh kenyataan adanya kesatuan-kesatuan sosial berdasarkan perbedaan suku bangsa, agama, adat, serta perbedaan kedaerahan, dan kedua secara vertikal ditandai oleh adanya perbedaan-perbedaan vertikal antara lapisan atas dan lapisan bawah yang cukup tajam. ${ }^{1}$ Hefner mengilustrasikan Indonesia sebagaimana juga Malaysia dan Singapura memiliki warisan dan tantangan pluralisme budaya (cultural pluralism) secara lebih mencolok, sehingga dipandang sebagai lokus klasik bagi bentukan baru masyarakat majemuk (plural society). ${ }^{2}$

Keberagaman tersebut selain mampu menjadi sebuah kekuatan dan kekayan serta kebanggaan tersendiri, akan tetapi kemajemukan tersebut pun menjadi sebuah tantangan tersendiri seperti halnya dapat memicu berbagai permasalahan. Sehingga jika diibaratkan multikulturalitas bangsa Indonesia ini dapat diibaratkan sebuah pisau yang memiliki mata ganda. Di satu sisi ia dapat menjadi potensi yang berharga dalam membangun peradaban bangsa, namun disisi lain apabila tidak dapat dikendalikan dengan sebaik mungkin, multikulturalitas tersebut akan melahirkan berbagai macam konflik yang mampu memecah belah sendi-sendi persatuan dan kehidupan dalam berbangsa dan bernegara bahkan disintegrasi bangsa.

1 Nasikun, Sistem Sosial Indonesia. Jakarta: pt. RajaGrafindo Persada., 2007. Hal. 33

2 Hefner, Robert W. Politik Multikulturalisme: Menggugat Realitas Kebangsaan. Terjemahan oleh Bernardus Hidayat dari judul asli The Politics of Multiculturalism, Pluralism and Citizenship in Malaysia, Singapore, and Indonesia. Yogyakarta: Kanisius, 2007. Hal. 16
Kemajemukan masyarakat Indonesia paling tidak dapat dilihat dari dua cirinya yang unik, pertama secara horizontal, ia ditandai oleh kenyataan adanya kesatuan-kesatuan sosial berdasarkan perbedaan suku bangsa, agama, adat, serta perbedaan kedaerahan, dan kedua secara vertikal ditandai oleh adanya perbedaan-perbedaan vertikal antara lapisan atas dan lapisan bawah yang cukup tajam. ${ }^{3}$ Sehingga perbedaan-perbedaan tersebut akan menjadi beban atau kekayaan tergantung bagaimana cara mengolahnya. Dengan semboyan Bhineka Tunggal Ika yang telah dicetuskan oleh para founding fathers bangsa ini, diharapkan masyarakat Indonesia dapat hidup bersama berdampingan dalam suasana aman, damai, dan sejahtera. Sehingga sebagai usaha dalam meningkatkan apresiasi siswa terhadap kearifan lokal tidak akan lepas dari peran sebuah lembaga pendidikan. Sehingga menurut Muhaimin yang dikutip Sapendi menyatakan, ada tiga kunci pokok yang dapat dipakai untuk mengembangkan pendidikan multikultural. Pertama, diintegrasikan melalui pembelajaran dengan metode diskusi pada kelompok-kelompok kecil. Kedua, berupa kepekaan terhadap informasi terutama berkaitan isu-isu masyarakat multikultural, sebab didalamnya terdapat ethno-kultural dan agama, demokrasi dan pluralitas, kemanusiaan universal dan subyek lain yang relevan. Ketiga, mengubah paradigma dengan menanamkan sikap saling menghormati, tulus dan toleran terhadap keanekaragaman budaya ditengah masyarakat, dengan memperkuat basik spiritual yang peka terhadap masalah sosial-keagamaan. ${ }^{4}$

Dari latarbelakang diatas dapat dirumuskan bagaimana urgensi pendidikan multikultural disekolah sebagai usaha dalam meningkatkan apresiasi siswa terhadap budaya lokal. Sehingga tujuan tulisan ini berusaha memaparkan bagaimana

3 Opcite, Nasikun, Sistem Sosial..... Hal. 33

4 Sapendi, INTERNALISASI NILAI-NILAI MULTIKULTURAL DALAM PEMBELAJARAN PENDIDIKAN AGAMA ISLAM DI SEKOLAH (Pendidikan Tanpa Kekerasan), RAHEEMA: Jurnal Studi Gender dan Anak 
urgensi pendidikan multikulutal tersebut dan bagaimana implementasinya didalam satuan pendidikan. Penelitian ini bersifat deskriptif analitik yaitu menggunakan teori-teori para ahli tentang pendidikan multikultural dalam ruang merawat budaya lokal yang kemudian dilakukan analisa agar ditemukan titik efektifitas terhadap urgensi pendidikan multikultural.

\section{Pembahasan}

\section{Konsep Pendidikan Multikultural}

Pengertian Pendidikan Multikultural adalah merupakan suatu gerakan pembaharuan dan proses untuk menciptakan lingkungan pendidikan yang setara untuk seluruh siswa. Sebagai sebuah gerakan pembaharuan, istilah pendidikan multikultural masih dipandang asing bagi masyarakat umum, bahkan penafsiran terhadap definisi maupun pengertian pendidikan multikultural juga masih diperdebatkan di kalangan pakar pendidikan. Seperti pendapat Andersen dan Cusher bahwa pendidikan multikultural diartikan sebagai pendidikan mengenai keragaman kebudayaan. ${ }^{5}$ Kemudian James Banks mendefinisikan pendidikan multikultural sebagai pendidikan untuk people of color. ${ }^{6}$ Artinya pendidikan multikultural ingin mengeksplorasi perbedaan sebagai keniscayaan (anugrah Tuhan/ sunatullah) kemudian bagaimana kita mampu mensikapi perbedaan tersebut dengan penuh toleran dan semangat egaliter. ${ }^{7}$

Sedangkan Hernandez, mengartikan pendidikan multikultural sebagai perspektif yang mengakui realitas sosial, politik, dan ekonomi yang dialami oleh masing-masing individu dalam pertemuan manusia yang kompleks dan beragam

5 Mahfud, Choirul. Pendidikan Multikultura, Yogyakarta : Pustaka Pelajar. 2008, Hal.175

6 Ibid,

7 Ibid, secara kultur, dan merefleksikan pentingnya budaya, ras, seksualitas dan gender, etnisitas, agama, status social, ekonomi, dan pengecualian-pengecualian dalam proses pendidikan. ${ }^{8}$ Ahli lain, Sleeter dan Grant dan Smith sebagaimana dikutip Zamroni mendefinisikan pendidikan multikultural sebagai suatu pendekatan progresif untuk melakukan transformasi pendidikan yang secara holistik memberikan kritik dan menunjukkan kelemahankelemahan, kegagalan-kegagalan dan diskriminasi yang terjadi di dunia pendidikan. ${ }^{9}$

Sejalan dengan berbagai pemikiran diatas maka disini Muhaemin el Ma'hadi berpendapat bahwa secara sederhana pendidikan multikultural dapat didefinisikan sebagai pendidikan tentang keragaman kebudayaan dalam merespon perubahan demografis dan kultural lingkungan masyarakat tertentu atau bahkan dunia secara keseluruhan (global). ${ }^{10}$ Sehingga Multikulturalisme adalah landasan budaya yang terkait dengan pencapaian civility (keadaban), yang amat esensial bagi terwujudnya demokrasi yang berkeadaban, dan keadaban yang demokratis. ${ }^{11}$

Multikultural merupakan suatu konsep dan implementasi yang belum sepenuhnya disadari segenap warga masyarakat. Setiap manusia terlahir dalam keadaan berbeda satu sama lain, membawa sejumlah karakter fisik dan psikis yang berbeda, di samping itu setiap individu memiliki sistem keyakinan, yang berbeda belum sepenuhnya bisa diterima dengan nalar kolektif masyarakat. Nalar kolektif masyarakat tentang multikultural masih terkooptasi logisentrisme, tafsir hegemonik yang

8 Hernandez, Hilda. Multicultural Education: A teacher Guide to linking Context, Process, and Content, New Jersy \& Ohio : Prentice Hall. 1989.

9 Zamroni, Pendidikan Demokrasi pada Masyarakat Multikultural.Yogyakarta: Gavin Kalam Utama, 2011.Hal.114

${ }^{10}$ Muhaemin el Ma'hadi, Multikulturalisme dan Pendidikan Multikultural, 27 Mei 2004

11 Azra, Azyumardi, Demokrasi Multikultural . Harian Republika, 12 Agustus 2004. 
sarat prasangka, curiga, kebencian, dan reduksi terhadap kelom-pok yang ada diluar dirinya. Tingkat pemahaman masyarakat Indonesia tentang multikultural sangat beragam. Namun demikian, pada mayoritas masyarakat Indonesia telah sadar akan pentingnya multikultural ini sebagai kekuatan bangsa, dan bukannya potensi untuk mencerai beraikan persatuan dan kesatuan.

Secara konseptual, ${ }^{12}$ M.G.Smith dalam Abdul Rachman mendefinisikan bahwa multikultural bangsa sebagai sesuatu yang lebih dari hanya keragaman kebudayaan. Masyarakat yang benarbenar bersifat plural hanyalah apabila ada sesuatu keanekaragaman yang resmi (diakui) di dalam sistem dasar dari kelembagaan-kelembagaan yang diwajibkan. Kejelasan dari konsep M.G.Smith karena ia bertolak dari premis bahwa sistem kelembagaan apapun cenderung mengarah kepada integrasi dan kekentalan internal sementara setiap kelompok-kelompok yang berbeda akan cenderung membentuk suatu kesatuan sosial budaya yang berdekatan.

Terlepas dari konteks wilayah dan zaman yang memang sangat berpengaruh munculnya sebuah konsep, namun kecenderungan adanya penyeragaman terhadap bermacam-macam suku bangsa. Kecenderungan ini akan menempatkan suku bangsa tertentu yang mayoritas sebagai unsur yang berhak mengatasnama dirinya "mewakili masyarakat". Walau-pun pada kenyataannya dapat menimbulkan sikap primodial yang mengutamakan kepentingan suatu kelompok atau komunitas masyarakat tertentu.

Pada dasarnya manusia menciptakan budaya atau lingkungan sosial mereka sebagai suatu adaptasi terhadap lingkungan fisik dan biologis mereka. Kebiasaan-kebiasaan, praktek-praktek, dan tradisi-tradisi untuk terus hidup dan berkembang diwariskan oleh suatu generasi ke generasi lainnya dalam suatu masyarakat tertentu. Pada gilirannya

${ }^{12}$ Dadang Syahroni, http://dedimulyana96.blogspot. co.id/2015/03/makalah-persatuan-dan-kesatuan-bangsa.html. kelompok atau suku bangsa tersebut tidak menyadari dari mana asal warisan kebijaksanaan tersebut. Generasi berikutnya terkondisikan untuk menerima "kebenaran-kebenaran" tersebut tentang kehidupan di sekitar mereka, karena norma dan nilai tertentu telah ditetapkan oleh generasi sebelumnya. Namun demikian, norma dan nilai tertentu dari suatu daerah atau suku bangsa, dapat diterima atau tidak tergantung dari persepsi, pengetahuan dan keyakinan dari orang-orang yang bersangkutan.

Pada umumnya individu-individu cenderung menerima dan mempercayai apa yang dikatakan budaya mereka. Hal ini dapat dipahami, karena manusia yang hidup tumbuh dan berkembang dipengaruhi oleh keluarga dan masyarakat dimana kita dibesarkan dan tinggal. Tentunya terlepas dari bagaimana validatas obyektif masukan dan penanaman budaya ini pada diri kita. Pada umumnya individu akan mengabaikan atau menolak apa yang bertentangan "kebenaran" kultural atau bertentangan dengan kepercayan-kepercayaan yang diyakininya.

Budaya adalah gaya hidup unik suatu kelompok manusia tertentu (Dedi Mulyana,2001). Budaya merupakan pengetahuan yang dapat dikomunikasikan, sifat-sifat perilaku dipelajari yang juga ada pada anggota-anggota dalam suatu kelompok sosial dan berwujud dalam lembagalembaga artefak-artefak mereka. E.B.Taylor, pakar Antropologi menyebutkan budaya sebagai keseluruhan dimensi meliputi pengetahuan, kepercayaan, seni, moral, hukum, adat istiadat, dan kemampuan-kemampuan atau kebiasaankebiasaan lain yang diperoleh angggota-anggota suatu masyarakat. Dalam hal ini setiap kelompok budaya menghasilkan jawaban-jawaban khususnya sendiri terhadap tantangan-tantangan hidup seperti kelahiran, pertumbuhan, hubungan-hubungan sosial, dan bahkan kematian.

Sebagaimana telah kita ketahui bahwa budaya memberikan identitas kepada sekelompok orang terhadap karakteristik kulturnya. Beberapa aspek 
budaya tampak jelas dalam perilaku manusia, namun ada pula aspek lainnya tersembunyi. Sebagian dari aspek-aspek budaya ini eksplisit dalam adat dan pengetahuan masyarakat, dan mungkin berwujud dalam hukum adat, tradisi-tradisi yang dipercayai oleh kelompok masyarakatnya.

Di antara sekian banyak definisi budaya, ada definisi yang menyebutkan budaya sebagai rancangan-rancangan yang tercipta secara historis untuk hidup untuk hidup yang bisa rasional, irasional dan nonrasional. Perilaku rasional dalam suatu budaya didasarkan atas apa yang dianggap kelompok masuk akal untuk mencapai tujuantujunannya. Perilaku irasional menyimpang dari norma-norma yang diterima suatu masyarakat dan mungkin bersumber dari frustasi seseorang dalam usaha memuaskan kebutuhan-kebutuhannya. Perilaku irasional akan dilakukan orang tanpa disertai logika dan kemungkinan besar sebagai suatu respons emosional. Perilaku nonrasional tidak berdasarkan logika, tidak juga bertentangan dengan ekspetasi-ekspetasi yang masuk akal. Banyak perilaku termasuk ke dalam kedua jenis ini. Kita tidak menyadari mengapa kita melakukan perilaku itu, mengapa kita mempercayai yang kita lakukan, atau bahwa mungkin berpra-sangka menurut pandangan orang-orang di luar kelompok budaya kita.

Manusia menciptakan budaya tidak hanya sebagai suatu mekanisme adaptif terhadap lingkungan biologis dan geofisik mereka tetapi juga sebagai alat untuk memberikan adil dari evolusi sosial kita. Dengan demikian manusia sebagai mahluk individu, akan melekat sifat-sifat bawaan yang dapat disebabkan dari sifat generasi manusia sebelumnya. Dalam perkembangannya lingkungan geofisik dimana kita tinggal dan berada seperti rumah, sekolah, tempat ibadah, tempat kantor, atau tempat lainnya memberikan konteks budaya yang berpengaruh terhadap perilaku kita. Budaya memudahkan kehidupan untuk memecahkan masalah-masalah dengan menerapkan pola-pola hubungan, dan cara-cara memelihara kohesi dan konsensus kelompok. Banyak cara atau pendekatan yang berlainan untuk menganalisis dan mengkategorikan suatu budaya agar budaya tersebut lebih mudah dipahami.

Secara sederhana pendidikan multikultural, dapat didefinisikan sebagai "pendidikan untuk/ tentang keragaman kebudayaan dalam merespon perubahan demografis dan kultural lingkungan masyarakat tertentu atau bahkan dunia secara keseluruhan". ${ }^{13}$ Pendidikan multikultural dapat dilihat dari 3 (tiga) aspek: konsep, gerakan, dan proses. ${ }^{14}$ Dari aspek konsepnya, pendidikan multikultural dipahami sebagai ide yang memandang semua siswa tanpa memperhatikan gender dan kelas sosial mereka, etnik mereka, ras mereka, dan atau karakteristik-karakteristik kultural lainnya memiliki kesempatan yang sama untuk belajar di kelas. Dari aspek gerakannya, pendidikan multikultural didefinisikan sebagai usaha untuk mengubah sekolah-sekolah dan institusiinstitusi pendidikan sehingga siswa dari semua kelas sosial, gender, ras, dan kelompok-kelompok kultural memiliki kesempatan yang sama untuk belajar. Perubahan yang dilakukan tidak hanya terbatas pada kurikulum, tetapi juga aspek lain seperti metode, strategi, manajemen pembelajaran, dan lingkungan sekolah. Dari aspek prosesnya, pendidikan multikultural dapat dipahami sebagai proses untuk mencapai tujuan agar kesetaraan pendidikan dapat dicapai oleh semua siswa. Kesetaraan pendidikan, seperti kemerdekaan dan keadilan tidak mudah dicapai, karena itu proses ini harus berlangsung terus-menerus.

${ }^{13}$ Rustam Ibrahim, ADDIN, Vol. 7, No. 1, Februari 2013

${ }^{14}$ Sapendi, INTERNALISASI NILAI-NILAI MULTIKULTURAL DALAM PEMBELAJARAN PENDIDIKAN AGAMA ISLAM DI SEKOLAH (Pendidikan Tanpa Kekerasan), RAHEEMA: Jurnal Studi Gender dan Anak 


\section{Pengembangan Kurikulum Pendidikan Multikultural di Sekolah}

Wacana pendidikan multikulturalisme memang sempat menghangat di media masa dan banyak menjadi bahan diskusi di sejumlah forum, tapi sayangnya tidak diikuti dengan sejumlah upaya secara sungguh-sungguh dan kontinue untuk mempormulasikannya kedalam gagasan yang lebih aflikatif. Bahkan dapat dikatakan, upaya mempromosikan konsep pendidikan multikultural sebagai bagian dari upaya meredam potensi konflik horisontal maupun vertikal bangsa akibat salah paham soal SARA belum berjalan secara signifikan.

Sebagai implikasinya, upaya-upaya memperlunak kebekuan dan mencairkan kekakuan pemikiran keagamaan dan kemanusiaan dari masing- masing agama dan budaya belum dianggap terlalu penting untuk digiring kearah pendidikan. Mulai dari segi materi dan metodelogi yang diajarkan disekolah, pesantren, seminar, dan masyarakat umumnya, memiliki kencenderungan untuk mengajarkan pendidikan agama secara parsial (kulitnya saja).

Implementasi pendidikan multikultur pada jenjang pendidikan dasar dan menengah, dapat dilakukan secara komprehensif melalui pendidikan kewargaan dan melalui Pendidikan Agama, dapat dilakukan melalui pemberdayaan slotslot kurikulum atau penambahan atau perluasan kompetensi hasil belajar dalam konteks pembinaan akhlak mulia, memiliki intensitas untuk membina dan mengembangkan kerukunan hidup antar umat beragama, dengan memberi penekanan pada berbagai kompetensi dasar sebagaimana telah terpapar di atas. Kemudian, juga harus dilakukan dalam pendekatan deduktif dengan kajian yang relevan, kemudian dikembangkan menjadi normanorma keagamaan, norma hukum, etik, maupun norma sosial kemasyarakatan. ${ }^{15}$

${ }^{15}$ https://alvazghany.wordpress.com/2012/11/09/ membumikan-pendidikan-multikultural-di-sekolahan/
Perbedaan-perbedaan pada diri anak didik yang harus diakui dalam pendidikan multikultural, antara lain mencakup penduduk minoritas etnis dan ras, kelompok pemeluk agama, perbedaan agama, perbedaan jenis kelamin, kondisi ekonomi, daerah/asal-usul, ketidakmampuan fisik dan mental, kelompok umur, dan lain-lain. ${ }^{16}$ Melalui pendidikan multikultural ini anak didik diberi kesempatan dan pilihan untuk mendukung dan memperhatikan satu atau beberapa budaya, misalnya sistem nilai, gaya hidup, atau bahasa. ${ }^{17}$

Pendidikan multikultural bisa muncul berbentuk bidang studi, program dan praktik yang direncanakan lembaga pendidikan untuk merespon tuntutan, kebutuhan, dan aspirasi berbagai kelompok. Sebagaimana ditunjukkan oleh Grant dan Seleeten dalam Sutarno, ${ }^{18}$ Meminjam sistem klasifikasi Robinson, Nasikun menyampaikan bahwa ada tiga perspektif multikulturalisme di dalam sistem pendidikan: (1) perspektif "cultural assimilation"; (2) perspektif"cultural pluralism"; dan (3) perspektif"cultural synthesis". ${ }^{19}$

James Banks menjelaskan bahwa pendidikan multikultural memiliki lima dimensi yang saling berkaitan dan dapat membantu guru dalam mengimplementasikan beberapa program yang mampu merespon terhadap perbedaan pelajar (siswa), ${ }^{20}$ yaitu: Dimensi integrasi isi/materi (content integration), Dimensi konstruksi pengetahuan (knowledge construction), Dimensi pengurangan prasangka (prejudice ruduction),

${ }^{16}$ Baker G.C.Planning dan Organizing for Multicultural Instruction. (2nd). California: Addison-Elsey Publishing Company, 1994. Hal. 11

${ }^{17}$ http://eprints.uny.ac.id/307/1/PENDIDIKAN_ MULTIKULTURAL_DALAM_PLURALISME_ BANGSA.pdf

${ }^{18}$ Sutarno. Pendidikan Multikultural. Jakarta: Ditjen Dikti.(2007)

${ }^{19}$ Nasikun. Imperatif Pendidikan Multikultural di Masyarakat Majemuk. Makalah. Disampaikan di Universitas Muhammadiyah Surakarta Sabtu, 8 Januari 2005 di Ruang Seminar FE UMS.

${ }^{20}$ James Banks, Multiethnic Education: Theory and Practice, 3rd ed. Boston; Allyn and Boston, 1994. Hal. 196. 
Dimensi pendidikan yang sama/adil (equitable pedagogy) dan Dimensi pemberdayaan budaya sekolah dan struktur sosial (empowering school culture and social structure). ${ }^{21}$

Dari aspek metodik, strategi dan manajemen pembelajaran merupakan aspek penting dalam pendidikan multikultural. Harry K. Wong, penulis buku How to be an Active Teacher the First Days of School, sebagaimana dikutip Linda Starr mendefinisikan manajemen pembelajaran sebagai "praktik dan prosedur yang memungkinkan guru mengajar dan siswa belajar." Terkait dengan praktik dan prosedur ini, Ricardo L. Garcia dalam Blajan Konradus $^{22}$ menyebutkan 3 (tiga) faktor dalam manajemen pembelajaran, yaitu:

\section{Lingkungan fisik (physical environment)}

Untuk menciptakan lingkungan fisik yang aman dan nyaman, guru dapat mempertimbangkan aspek pencahayaan, warna, pengaturan meja dan kursi, tanaman, dan musik. Guru yang memiliki pemahaman terhadap latar belakang budaya siswanya, akan menciptakan lingkungan fisik yang kondusif untuk belajar.

\section{Lingkungan sosial (buman environment)}

${ }^{21}$ Content Integration: Dimensi ini digunakan oleh guru untuk memberikan keterangan dengan "poin kunci" pembelajaran dengan merefleksi materi yang berbeda-beda. Knowledge construction: Suatu dimensi dimana para guru membantu siswa untuk memahami beberapa perspektif dan merumuskan kesimpulan yang dipengaruhi oleh disiplin pengetahuan yang mereka miliki. Prejudice ruduction: Guru melakukan banyak usaha untuk membantu siswa dalam mengembangkan perilaku positif tentang perbedaan kelompok. Equitable pedagogy: Dimensi ini memperhatikan cara-cara dalam mengubah fasilitas pembelajaran sehingga mempermudah pencapaian hasil belajar pada sejumlah siswa dari berbagai kelompok. Empowering school culture and social structure: Dimensi ini penting dalam memperdayakan budaya siswa yang dibawa ke sekolah yang berasal dari kelompok yang berbeda. Lihat. Rustam Ibrahim, ADDIN, Vol. 7, No. 1, Februari 2013

${ }^{22}$ Blajan Konradus, Majalah Ilmiah INDIKATOR, Volume XIII, Nomor 1, Maret 2011 lihat. http:// jurnalonlineuniflor.blogspot.co.id/2012/04/majalah-ilmiahindikator-edisi-maret_17.html
Lingkungan sosial yang aman dan nyaman dapat diciptakan oleh guru melalui bahasa yang dipilih, hubungan simpatik antar siswa, dan perlakuan adil terhadap siswa yang beragam budayanya.

\section{Gaya pengajaran guru (teaching style).}

Selain lingkungan fisik dan-sosial, siswa juga memerlukan gaya pengajaran guru yang menggembirakan. Menurut Garcia gaya pengajaran guru merupakan gaya kepemimpinan atau teknik pengawalan yang digunakan guru dalam proses pembelajaran (the kind of leadership or governance techniques a teacher uses). Dalam proses pembelajaran, gaya kepemimpinan guru sangat berpengaruh bagi ada-tidaknya peluang siswa untuk berbagi pendapat dan membuat keputusan. Gaya kepemimpinan guru berkisar pada otoriter, demokratis, dan bebas (laizzes faire). Gaya kepemimpinan otoriter tidak memberikan peluang kepada siswa untuk saling berbagi pendapat. Apa yang diajarkan guru kepada siswa ditentukan sendiri oleh sang guru. Sebaliknya, gaya kepemimpinan guru yang demokratis memberikan peluang kepada siswa untuk menentukan materi yang perlu dipelajari siswa. Selanjutnya, guru yang menggunakan gaya kepemimpinan bebas (laizzes faire) menyerahkan sepenuhnya kepada siswa untuk menentukan materi pembelajaran di kelas. Untuk kelas yang beragam latar belakang budaya siswanya, agaknya, lebih cocok dengan gaya kepemimpinan guru yang demokratis.

Adapun pendekatan dalam pendidikan multikultural telah berkembang sejak tahun 1960-an dapat diidentifikasi dengan empat pendekatan yang mengintegrasikan materi etnis dan multikultural ke dalam kurikulum:

1. Pendekatan Kontribusi (the contribution approach)

Pendekatan ini mencerminkan sedikitnya jumlah keterlibatan dalam pendekatan pendidikan multikultural. Hal ini dimasukkan dengan memilih buku-buku dan kegiatan yang merayakan hari libur, 
pahlawan, dan acara khusus dari berbagai budaya.

\section{Pendekatan Aditif (The Additive Approach)} Dalam konten ini pendekatan, konsep, tema, dan perspektif ditambahkan ke kurikulum tanpa mengubah struktur dasar. Ini melibatkan menggabungkan literatur oleh dan tentang orang-orang dari beragam budaya ke dalam kurikulum utama tanpa mengubah kurikulum. Sebagai contoh, memeriksa perspektif asli Amerika tentang Thanksgiving akan menambahkan keragaman budaya dengan pandangan tradisional Thanksgiving.

3. Pendekatan Transformasi (The Transformation Approach)

Pendekatan ini benar-benar mengubah struktur kurikulum dan mendorong siswa untuk melihat konsep, isu, tema, dan masalah dari perspektif etnik dan beberapa sudut pandang. Sebagai contoh, sebuah unit pada Thanksgiving akan menjadi seluruh unit mengeksplorasi konflik budaya

4. Pendekatan Sosial Aksi (The Social Action Approach)

Pendekatan ini menggabungkan pendekatan transformasi dengan kegiatan untuk berjuang untuk perubahan sosial. Siswa tidak hanya diperintahkan untuk memahami dan pertanyaan isu-isu sosial, tapi juga melakukan sesuatu yang penting tentang hal itu.

\section{Memelihara Persatuan dalam Perbedaan}

Kebijakan yang sentralistis dan pengawalan yang ketat terhadap isu perbedaan telah menghilangkan kemampuan masyarakat untuk memikirkan, membicarakan dan memecahkan persoalan yang muncul dari perbedaan secara terbuka, rasional dan damai. Sejarah menunjukkan, pemaknaan secara negatif atas keragaman telah melahirkan penderitaan panjang bagi umat manusia. Di Indonesia sendiri, konflik kekerasan yang melibatkan suku, agama, ras dan golongan (SARA) masih sering terjadi. Berbagai peristiwa berdarah seperti di ambon, poso, sampit, sambas dan berbagai daerah lainnya memberikan gambaran betapa rentannya gesekan yang terjadi akibat adanya perbedaan pandangan, pola hidup dan gesekan kebudayaan antara masyarakat mayoritas dan minoritas.

Rapuhnya kehidupan berbangsa dan bernegara serta pengakuan atas hak-hak asasi manusia saat ini mendorong munculnya gerakan pengakuan dan persamaan akan keragaman budaya serta eksistensinya di dalam masyarakat yang dikenal dengan istilah multikulturalisme. Secara sederhana multikulturalisme dapat dipahami sebagai sikap bagaimana masing-masing kelompok bersedia untuk menyatu (integrate) tanpa mempedulikan keragaman budaya yang dimiliki. Mereka semua melebur, sehingga pada akhirnya ada proses "hibridisasi" yang meminta setiap individu untuk tidak menonjolkan perbedaan masing-masing kultur.

Sebuah kesadaran akan pentingnya multikulturalisme tersebut hanya dapat berkembang dengan baik apabila secara terus-menerus dilatihkan dan dididikkan pada generasi-generasi selanjutnya melalui pendidikan. Dengan pendidikan, sikap saling menghargai terhadap perbedaan akan berkembang bila generasi penerus dilatih dan disadarkan akan pentingnya penghargaan pada orang lain dan budaya lain. Oleh karena pendidikan multicultural sangat diperlukan untuk mengatasi berbagai konflik horizontal, seperti keragaman suku, ras dan agama serta konflik vertical seperti tingkat pendidikan, ekonomi dan sosial budaya bangsa Indonesia.

Peran pendidikan di dalam multikulturalisme hanya dapat dimengerti di dalam kaitannya dengan falsafah hidup, kenyataan sosial, yang akan meliputi disiplin-disiplin yang lain seperti agama, social science, antropologi, sosiologi dsb. Dengan demikian 
multikulturalisme dan pendidikan bukanlah masalah teknis pendidikan belaka, tetapi memerlukan suatu konsep pemikiran serta pengembangan yang meminta partisipasi antar disiplin. Pendidikan multikultural dapat dijadikan sarana untuk mengikis perbedaan-perbedaan yang dapat menjadi buah bagi adanya perpecahan.

Realitas suatu bangsa yang menunjukkan adanya kondisi keanekaragaman budaya, mengarahkan pada pilihan untuk menganut asas multikulturalisme. Dalam asas multikulturalisme ada kesadaran bahwa bangsa itu tidak tunggal, tetapi terdiri atas sekian banyak komponen yang berbeda. Multikluturalisme menekankan prinsip tidak ada kebudayaan yang tinggi dan tidak ada kebudayaan yang rendah di antara keragaman budaya tersebut. Semua kebudayaan pada prinsipnya sama-sama ada dan karena itu harus diperlakukan dalam konteks duduk sama rendah dan berdiri sama tinggi. Asas itu pulalah yang diambil oleh Indonesia, yang kemudian dirumuskan dalam semboyan yaitu "bbineka tunggal $i k a$ ".

"Bhinneka Tunggal Ika" merupakan alat pemersatu bangsa. Bhinneka Tunggal Ika merupakan semboyan bangsa kita yang mengungkapkan persatuan dan kesatuan yang berasal dari keanekaragaman. Walaupun kita terdiri atas berbagai suku yang beranekaragam budaya daerah, namun kita tetap satu bangsa Indonesia, memiliki bahasa dan tanah air yang sama, yaitu bahasa Indonesia dan tanah air Indonesia. Begitu juga bendera kebangsaan merah putih sebagai lambang identitas bangsa dan kita bersatu padu di bawah falsafah dan dasar negara Pancasila.

Realitas historis menunjukkan bahwa bangsa Indonesia berdiri tegak di antara keragaman budaya yang ada. Salah satu contoh nyata yaitu dengan dipilihnya bahasa Melayu sebagai akar bahasa persatuan yang kemudian berkembang menjadi bahasa Indonesia. Dengan kesadaran yang tinggi semua komponen bangsa menyepakati sebuah konsensus bersama untuk menjadikan bahasa Melayu sebagai bahasa persatuan yang dapat mengatasi sekaligus menjembatani jalinan antarkomponen bangsa.

Adat istiadat, kesenian, kekerabatan, bahasa, dan bentuk fisik yang dimiliki oleh suku-suku bangsa yang ada di Indonesia memang berbeda, namun selain perbedaan suku-suku itu juga memiliki persamaan antara lain hukum, hak milik tanah, persekutuan, dan kehidupan sosialnya yang berasaskan kekeluargaan.

Untuk dapat bersatu kita harus memiliki pedoman yang dapat menyeragamkan pandangan kita dan tingkah laku kita dalam kehidupan seharihari. Dengan demikian, akan terjadi persamaan langkah dan tingkah laku bangsa Indonesia. Pedoman tersebut adalah Pancasila, kita harus dapat meningkatkan rasa persaudaraan dengan berbagai suku bangsa di Indonesia.

Membiasakan bersahabat dan saling membantu dengan sesama warga yang ada di lingkungan kita, seperti gotong royong akan dapat memudahkan tercapainya persatuan dan kesatuan bangsa. Bangsa Indonesia harus merasa satu, senasib sepenanggungan, sebangsa, dan sehati dalam kekuatan wilayah nasional dengan segala isi dan kekayaannya merupakan satu kesatuan wilayah.

Dalam pandangan Koentjaraningrat Indonesia dapat disebut sebagai negara plural terlengkap di dunia di samping negara Amerika. ${ }^{23}$ Di Amerika dikenal semboyan et pluribus unum, yang mirip dengan bhineka tunggal ika, yang berarti banyak namun hakikatnya satu. Semboyan Bhineka Tunggal Ika memang menjadi sangat penting ditengah beragamnya adat dan budaya Indonesia. Menjadi barang percuma, apabila semboyan penuh makna tersebut hanya menjadi pelengkap burung garuda penghias dinding. Bhineka Tunggal Ika bermakna berbeda beda tetapi tetap satu jua, sebuah semboyan jitu yang terbukti berhasil menyatukan

${ }^{23}$ Koentjaraningrat, Masalab Kesukubangsaan dan Integrasi Nasional, Jakarta : UIP, 1993, Hal. 55 
bangsa dengan sejuta suku, bangsa yang kaya akan ideologi, menjadi sebuah bangsa yang utuh dan merdeka. Bhinneka Tunggal Ika merupakan alat pemersatu bangsa. Untuk itu kita harus benar-benar memahami maknanya. Negara kita juga memiliki alat-alat pemersatu bangsa yang lain, yakni:

1. Dasar Negara Pancasila

2. Bendera Merah Putih sebagai bendera kebangsaan

3. Bahasa Indonesia sebagai bahasa nasional dan bahasa persatuan

4. Lambang Negara Burung Garuda

5. Lagu Kebangsaan Indonesia Raya

6. Lagu-lagu perjuangan

Masih banyak alat-alat pemersatu bangsa yang sengaja diciptakan agar persatuan dan kesatuan bangsa tetap terjaga. Persatuan dalam keragaman memiliki arti yang sangat penting. Persatuan dalam keragaman harus dipahami oleh setiap warga masyarakat agar dapat mewujudkan hal-hal sebagai berikut :

1. Kehidupan yang serasi, selaras dan seimbang

2. Pergaulan antarsesama yang lebih akrab

3. Perbedaan yang ada tidak menjadi sumber masalah

4. Pembangunan berjalan lancar

Adapun sikap yang perlu dikembangkan untuk mewujudkan persatuan dalam keragaman antara lain:

1. Tidak memandang rendah suku atau budaya yang lain

2. Tidak menganggap suku dan budayanya paling tinggi dan paling baik

3. Menerima keragaman suku bangsa dan budaya sebagai kekayaan bangsa yang tak ternilai harganya

4. Lebih mengutamakan negara daripada kepentingan daerah atau suku masingmasing.
Kita mesti bangga, memiliki suku dan budaya yang beragam. Keragaman suku dan budaya merupakan kekayaan bangsa yang tak ternilai harganya. Bangsa asing saja banyak yang berebut belajar budaya daerah kita. Bahkan kita pun sempat kecolongan, budaya asli daerah kita

\section{Pendidikan Multikultural Dalam Meningkatkan Apresiasi Siswa Terhadap Kearifan Budaya Lokal}

Penyelenggaraan pendidikan multicultural didunia pendidkan diyakini dapat menjadi solusi nyata bagi konflik dan disharmonisasi yang terjadi di masyarakat. Oleh karena itu urgensi Pendidikan Multikultural Di Indonesia, dijabarkan sebagai berikut:

\section{Sebagai sarana alternatif pemecahan konflik}

Spectrum kultur masyarakat Indonesia yang amat beragam menjadi tantangan bagi dunia pendidikan guna mengolah perbedaan tersebut menjadi suatu asset, bukan sumber perpecahan. Saat ini, pendidikan multicultural mempunyai dua tanggung jawab besar, yaitu menyiapkan bangsa Indonesia untuk siap menghadapi arus budaya luar di era globalisasi dan menyatukan bangsa sendiri yang terdiri dari berbagai macam budaya.

Memang pendidikan kebangsaan dan ideology telah banyak diberikan diperguruan tinggi, namun pendidikan multicultural belum diberikan dengan proporsi yang benar. Maka, sekolah dan perguruan tinggi sebagai institusi pendidikan dapat mengembangkan pendidikan multicultural dengan model masing-masing sesuai asas otonomi pendidikan atau sekolah. Pendidikan multicultural sebaiknya lebih ditekankan pada mata pelajaran kebangsaan dan moral.

Pada dasarnya, model-model pembelajaran sebelumnya yang berkaitan dengan kebangsaan memang sudah ada. Namun, hal itu masih kurang memadai sebagai sarana pendidikan guna 
menghargai perbedaan masing-masing suku, budaya, etnis. Hal itu terlihat dengan munculnya konflik yang kerap terjadi pada realitas kehidupan berbangsa dan bernegara saat ini. Hal itu menunjukkan bahwa pemahaman toleransi masih amat kurang.

Hingga detik ini, jumlah siswa dan mahasiswa yang memahami apa yang sebenernya ada di balik budaya suatu bangsa masih sangat sedikit. Menurut Suyanto, pakar pendidikan, masyarakat justru mengetahui lebih dalam mengenai stereotip suatu suku bangsa dibandingkan mengenal apa yang sebenarnya dimiliki suku tersebut. Padahal, dalam konteks diskursus pendidikan multicultural, memahami makna di balik realitas budaya suatu suku bangsa, itu merupakan hal yang esensial. Maka, penyelenggaraan pendidikan multicultural dapat dikatakan berhasil bila terbentuk pada diri siswa dan mahasiswa sikap hidup saling toleran, tidak bermusuhan dan tidak berkonflik yang disebabkan oleh perbedaan budaya, suku, bahasa, adat istiadat atau lainnya.

\section{Supaya Siswa Tidak Tercerabut dari Akar Budaya}

Selain sebagai sarana alternatif pemecahan konflik, pendidikan multicultural juga signifikan dalam membina siswa agar tidak tercerabut dari akar budaya yang ia miliki sebelumnya, tatkala ia berhadapan dengan realitas sosial budaya di era globalisasi. Dalam era globalisasi saat ini, pertemuan antarbudaya menjadi ancaman serius bagi anak didik. Untuk mensikapi realitas global tersebut, siswa hendaknya diberi penyadaran akan pengetahuan yang beragam, sehingga mereka memiliki kompetensi yang luas akan pengetahuan global, termasuk aspek kebudayaan.

Mengingat beragamnya realitas kebudayaan di Negara ini, dan di luar negeri, siswa pada era globalisasi ini sudah tentu perlu diberi materi tentang pemahaman banyak budaya, atau pendidikan multikulturalisme, agar siswa tidak tercerabut dari akar budayanya itu.
Dunia pendidikan kita saat ini sangat berat dan kompleks. Maka, upaya antisipasi perlu dipikirkan secara serius. Jika tidak ditanggapi dengan serius dan disertai solusi konkret, utamanya pada pendidikan kita yang bertanggung jawab penuh atas kualitas sumber daya manusia (SDM) dinegeri ini, maka anak-anak generasi bangsa ini bisa kehilangan arah, tercerabut dari akar budayanya sendiri. Coba kita bayangkan, jika persinggungan budaya hanya terjadi antar budaya yang berbeda, itu mungkin masih mudah di atasi. Tetapi, dalam era globalisasi seperti saat ini, pertemuan antar buadaya sudah luar biasa dan kompleks. Maka, jelas dimungkinkan terjadinya gesekan dan tarik ulur yang saling mempengaruhi antar budaya. Dan sangat dimungkinkan kekhawatiran Samuel P. Huntington dalam tesisnya The Clash of Civilization akan terwujud. Menurut H.A.R. Tilaar, pendidikan multicultural telah menjadi suatu tuntutan yang tidak dapat ditawar-tawar dalam membangun Indonesia baru. Dalam pandangan guru besar emeritus Program Pascasarjana UNJ ini, pendidikan multicultural memerlukan kajian yang mendalam mengenai konsep dan praksis pelaksanaanya. ${ }^{24}$

Konsep pendidikan multicultural belum dikaji secara serius pada dunia pendidikan kita. Tetapi, bila ditilik secara yuridis, sebetulnya UndangUndang Sistem Pendidikan Nasional tahun 2003 telah memberikan peluang untuk menjabarkan lebih lanjut terhadap konsep pendidikan multicultural, utamanya dalam pasal 4 ayat 1 yang mengatur tentang prinsip penyelenggaraan pendidikan yang mempertimbangkan nilai-nilai cultural masyarakat yang sangat beragam. Sebetulnya, realitas multicultural yang ada di Indonesia merupakan kekayaan yang bisa menjadi modal untuk mengembangkan suatu kekuatan budaya. Selain itu, ia juga sebagai kekayaan yang luar biasa, yang tidak dimiliki orang lain. Maka, jelas bahwa kekayaan tersebut patut kita jaga dan lestarikan.

${ }^{24}$ Berita Harian Republika, Jum'at 17 September 2004 


\section{Sebagai landasan Pengembangan Kurikulum Nasional}

Dalam melakukan pengembangan kurikulum sebagai titik tolak dalam proses belajar mengajar, atau guna memberikan sejumlah materi dan isi pelajaran yang harus dikuasai oleh siswa dengan ukuran atau tingkatan tertentu. Pendidikan multicultural sebagai landasan pengembangan kurikulum menjadi sangat penting.

Pemerintah, bersama para pakar dari PT, perlu menyusun konsep pendidikan multicultural untuk dimasukkan ke dalam kurikulum pendidikan. Sehingga, generasi muda memiliki ketahanan dan identitas nasional dan pada gilirannya ancaman disintegrasi bangsa dapat dicegah. Maka, pendidikan multicultural perlu dimasukan ke dalam kurikulum pendidikan, mulai SD hingga Perguruan Tinggi (PT), agar generasi muda Indonesia memiliki identitas nasional. Atau dapat juga dirumuskan materi tersendiri yang di dalamnya mencakup esensi pendidikan multicultural.

Dengan cara ini diharapkan bahwa generasi muda di Negara ini setidaknya-tidaknya memiliki identitas nasional, sehingga mereka tidak mudah dipecah belah, dan mampu bersaing di era perdagangan bebas dan era globalisasi seperti saat ini. Negara yang berpenduduk majemuk seperti Amerika, Australia dan Kanada pun telah mengajarkan pendidikan multicultural pada sekolah formal dan informal.

Menurut Hamid Hasan, ${ }^{25}$ bahwa masyarakat dan bangsa Indonesia memiliki keragaman sosial budaya, aspirasi politik dan kemampuan ekonomi. Keragaman tersebut berpengaruh langsung terhadap kemampuan guru dalam melaksanakan kurikulum, kemampuan sekolah dalam menyediakan pengelaman belajar, dan kemampuan siswa dalam berproses, belajar dan mengolah informasi menjadi

25 S. Hamid Hasan, Multikultural Untuk Penyempurnaan Kurikulum Nasional, Jurnal Pendidikan dan Kebudayaan, 026, 6, Oktober, 2000, 510-523 sesuatu yang dapat diterjemahkan sebagai hasil belajar. Keragaman itu menjadi suatu variable bebas yang memiliki kontribusi sangat signifikan terhadap keberhasilan kurikulum, baik sebagai proses maupun sebagai hasil.

Oleh karena itu, keragaman tersebut harus menjadi faktor yang diperhitungkan dalam menentukan filsafat, teori, visi, pengembangan dokumen, sosialisasi,dan pelaksanaan kurikulum. Pengembangkan kurikulum dengan menggunakan pendekatan pengembangan multicultural harus didasarkan pada empat prinsip. Pertama, keragaman budaya menjadi dasar dalam menentukan filsafat. Kedua, keragaman budaya dijadikan dasar dalam mengembangkan berbagai komponen kurikulum, seperti tujuan, konten, proses, dan evaluai. Ketiga, budaya dilingkungan unit pendidikan adalah sumber belajar dan objek studi yang harus dijadikan bagian dari kegiatan belajar siswa. Keempat, kurikulum berperan sebagai media dalam mengembangkan kebudayaan daerah dan nasional.

Keragaman sosial, budaya, aspirasi politik, dan kemampuan ekkonomi adalah suatu realita masyarakat dan bangsa Indonesia. Realitas tersebut memang berposisi sebagai objek peripheral dalam proses pengembangan kurikulum nasional. Posisi sebagai objek menguntungkan karena ia seringkali di abaikan oleh para otoritas pengembang kurikulum. Sayangnya, kedudukannya yang menjadi objek berubah menjadi subjek dan penentu dalam implementasi kurikulum, tetapi tetap dijadikan landasan ketika guru mengembangkan kurikulum. Padahal, keragaman itu seperti telah disebutkan berpengaruh langsung terhadap kemampuan guru dalam melaksanakan kurikulum, kemampuan sekolah dalam menyediakan pengalaman belajar, dan kemampuan siswa dalam berproses dalam belajar dan dalam mengolah informasi menjadi sesuatu yang dapat diterjemahkan sebagai hasil belajar.

Posisi keragaman sebagai variable bebas memang berada pada tataran sekolah dan 
masyarakat dimana suatu kurikulum dikembangkan dan diharapkan menjadi pengubah yang tangguh sesuai dengan kebutuhan masyarakat yang dapat diperkirakan (perceived needs of a society). Secara nyata, pengaruh tersebut berada pada diri guru yang bertanggungjawab terhadap pengembangan kurikulum, bukan pada siswa yang menjalani kurikulum. Ki Hadjar Dewantara menyatakan bahwa kebudayaan merupakan faktor penting sebagai akar pendidikan suatu bangsa. ${ }^{26}$

Ahli kurikulum lain seperti Print menyatakan pentingnya kebudayaan sebagai landasan bagi kurikulum dengan mengatakan : curriculum is a construct of that culture. ${ }^{27}$ Kebudayaan merupakan totalitas cara manusia hidup dan mengembangkan pola kehidupannya sehingga ia tidak saja menjadi landasan dimana kurikulum dikembangkan tetapi juga menjadi target hasil pengembangan kurikulum. Secara intrinsic, para pengembang kurikulum dalam merumuskan filosofi, visi dan tujuan pendidikan, sangat dipengaruhi oleh latar belakang pendidikan, pandangan hidup, dan keyakinan hidupnya.

\section{Menuju Masyarakat Indonesia yang Multikultural}

Bangunan Indonesia Baru dari hasil reformasi (perombakan tatanan kehidupan menuju tatanan yang lebih baik) di atas adalah terciptanya sebuah "masyarakat multikultural Indonesia". Dalam masyarakat multikultural ditegaskan, bahwa corak masyarakat Indonesia yang bhinneka tunggal ika ini bukan hanya dimaksudkan pada keanekaragaman suku bangsa, melainkan juga keanekaragaman kebudayaan yang ada dalam masyarakat Indonesia secara keseluruhan.

Eksistensi keberagaman kebudayaan tersebut selalu dijaga/ terjaga yang bisa tampak dalam sikap

${ }^{26}$ Ki Hajar Dewantara, Dasar-dasar pendidikan, dalam karya Ki Hajar Dewantara bagian pertama : pendidikan ( Yogyakarta : Majelis Luhur Persatuan Taman Siswa, 1936, 1945,1946

${ }^{27}$ M. Print, Curricullum Development and Design (St. Leonard : Allen \& Unwin Pty, Ltd, 1993. Hal. 201 saling menghargai, menghormati, toleransi antara satu kebudayaan dengan kebudayaan lainnya. Dalam konteks ini ditegaskan, bahwa perbedaan bukan menjadi penghalang untuk bersatu padu meraih tujuan dan mewujudkan cita-cita dalam kehidupan berbangsa dan bernegara sebagaimana termaktub dalam UUD 1945 dan Pancasila.

Model multikulturalisme ini sebenarnya telah digunakan sebagai acuan oleh para pendiri bangsa (founding fathers) Indonesia dalam mendesain apa yang dinamakan sebagai kebudayaan bangsa, sebagaimana yang terungkap dalam penjelasan Pasal 32 UUD 1945, yang berbunyi: "kebudayaan bangsa (Indonesia) adalah puncak kebudayaan di daerah". Upaya membangun Indonesia yang multikultural hanya mungkin dapat terwujud bila:

a. Konsep multikulturalisme menyebar luas dan dipahami urgensinya bagi bangsa Indonesia yang multicultural ini, juga adanya keinginan bangsa Indonesia pada tingkat nasional maupun lokal untuk mangadopsi dan menjadikannya sebagai pedoman hidup.

b. Adanya kesamaan pemahaman di antara para ahli mengenai makna multikulturalisme bagi kehidupan berbangsa dan bernegara.

c. Upaya-upaya lain yang dapat dilakukan guna mewujudkan cita-cita ini.

d. Konsep multikulturalisme tidaklah dapat disamakan dengan konsep keanekaragaman secara sukubangsa atau kebudayaan saja yang menjadi ciri masyarakat majemuk, karena multikulturalisme menekankan keanekaragaman kebudayaan dalam kesederajatan atau kesetaraan budaya.

\section{Kesimpulan}

Pendidikan Multikultural adalah merupakan suatu gerakan pembaharuan dan proses untuk menciptakan lingkungan pendidikan yang setara 
untuk seluruh siswa, Dari aspek konsepnya, pendidikan multikultural dipahami sebagai ide yang memandang semua siswa tanpa memperhatikan gender dan kelas sosial mereka, etnik mereka, ras mereka, dan atau karakteristik-karakteristik kultural lainnya memiliki kesempatan yang sama untuk belajar di kelas.Implementasi pendidikan multikultur pada jenjang pendidikan dasar dan menengah, dapat dilakukan secara komprehensif melalui pendidikan kewargaan dan melalui Pendidikan Agama, dapat dilakukan melalui pemberdayaan slotslot kurikulum atau penambahan atau perluasan kompetensi hasil belajar dalam konteks pembinaan akhlak mulia, memiliki intensitas untuk membina dan mengembangkan kerukunan hidup. Sehingga dalam hal ini terdapat empat pendekatan yang mengintegrasikan materi etnis dan multikultural ke dalam kurikulum yakni Pendekatan Kontribusi (the contribution approach), Pendekatan Aditif (The Additive Approach), Pendekatan Transformasi (The Transformation Approach), Pendekatan Sosial Aksi (The Social Action Approach).

\section{Daftar Pustaka}

Azra, Azyumardi, Demokrasi Multikultural. Harian Republika, 12 Agustus, 2004

Baker G.C. Planning dan Organizing for Multicultural Instruction. (2nd). California: Addison-Elsey Publishing Company, 1994

Berita Harian Republika,Jum'at 17 September 2004

Blajan Konradus, Majalah Ilmiah INDIKATOR, Volume XIII, Nomor 1, Maret 2011

Hefner, Robert W. Politik Multikulturalisme: Menggugat Realitas

Hernandez, Hilda. Multicultural Education: A teacher Guide to linking Context, Process, and Content, New Jersy \& Ohio : Prentice Hall, 1989
http://eprints.uny.ac.id/307/1/PENDIDIKAN_ MULTIKULT URA L_ D A L A M _ PLURALISME_BANGSA.pdf

James Banks, Multiethnic Education: Theory and Practice, 3rd ed. Boston; Allyn and Boston, 1994

Kebangsaan. Terjemahan oleh Bernardus Hidayat dari judul asli The Politics of Multiculturalism, Pluralism and Citizenship in Malaysia, Singapore, and Indonesia. Yogyakarta: Kanisius, 2007.

Ki Hajar Dewantara, Dasar-dasarpendidikan, dalam karya Ki Hajar Dewantara bagian pertama : pendidikan, Yogyakarta : Majelis Luhur Persatuan Taman Siswa, 1936, 1945, 1946.

Koentjaraningrat, Masalah Kesukubangsaan dan Integrasi Nasional, Jakarta : UIP, 1993

M. Print, Curricullum Development and Design, St. Leonard : Allen \& Unwin Pty, Ltd, 1993.

Mahfud, Choirul. Pendidikan Multikultura, Yogyakarta : Pustaka Pelajar, 2008

Muhaemin el Ma'hadi, Multikulturalisme dan Pendidikan Multikultural,27 Mei 2004

Nasikun, Sistem Sosial Indonesia. Jakarta: pt. RajaGrafindo Persada. 2007 , Imperatif Pendidikan Multikultural di Masyarakat Majemuk. Makalah. Disampaikan di Universitas Muhammadiyah Surakarta Sabtu, 8 Januari 2005 di Ruang Seminar FE UMS.

Rustam Ibrahim, ADDIN, Vol. 7, No. 1, Februari 2013

S. Hamid Hasan, Multikultural Untuk Penyempurnaan Kurikulum Nasional, Jurnal Pendidikan dan Kebudayaan, 026, 6, Oktober, 2000 
Sapendi, INTERNALISASI NILAI-

NILAI MULTIKULTURAL DALAM PEMBELAJARAN PENDIDIKAN AGAMA ISLAM DI SEKOLAH(Pendidikan Tanpa Kekerasan), RAHEEMA: Jurnal Studi Gender dan Anak.

Sutarno. Pendidikan Multikultural. Jakarta: Ditjen Dikti, 2007

Zamroni, Pendidikan Demokrasi pada Masyarakat Multikultural. Yogyakarta: Gavin Kalam Utama, 2011

\section{Internet}

http://jurnalonlineuniflor.blogspot.co.id/2012/04/ majalah-ilmiah-indikator-edisimaret_17.html https://alvazghany.wordpress.com/2012/11/09/ membumikan-pendidikanmultikultural-disekolahan/

http://dedimulyana96.blogspot.co.id/2015/03/ makalah-persatuan-dan-kesatuan bangsa.html

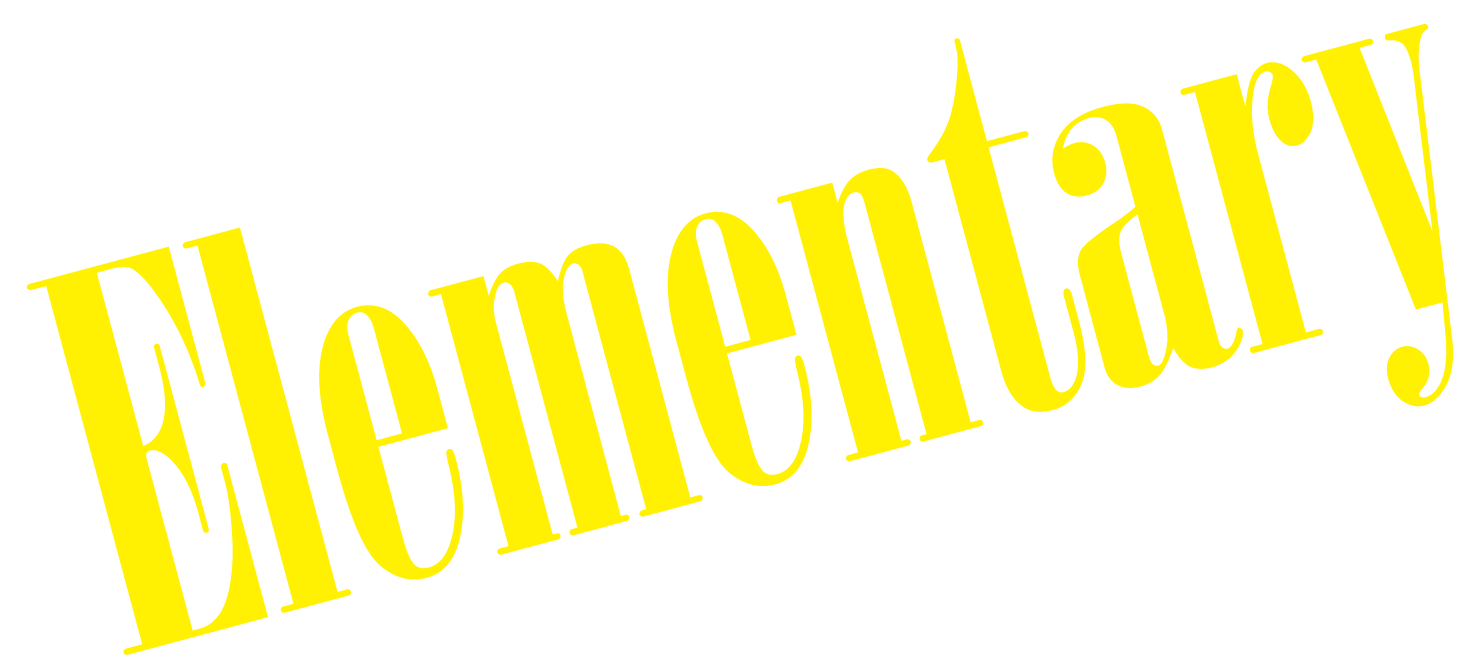

